\title{
水利水电工程管理的重要性及其应用分析
}

\author{
马杰 \\ 中国水电建设集团十五工程局有限公司 \\ DOI:10.32629/hwr.v4i7.3149
}

\begin{abstract}
[ 摘 要] 水利水电工程建设是社会基础设施建设的重要组成部分,对于社会经济的发展具有十分重要 的积极意义。由于水利水电工程的施工质量的好坏直接威胁影响到人们的生命财产安全,因此在水利水 电工程建设过程中的施工管理也显得尤为重要。但是水利水电工程管理工作中,往往存在着较为明显的 问题, 影响着水利水电工程的整体质量。水电工程管理的重要性及其应用进行了分析, 并更加现状提出改 进性的应用措施, 以供参考。
\end{abstract}

[关键词] 水利水电工程; 重要性; 管理

节水项目为我国的经济发展作出了 显著贡献, 特别是在洪水控制、排水和灾 害预防等领域, 这些项目产生了显著的 效益。然而, 近年来, 水利工程养护项目 的管理, 特别是在管理和技术方面, 出现 了一些消极的缺点。这要求我们总结和 改进我们的工作, 以便能够有效地预防 和处理各种问题。

\section{1 水利水电工程管理概述}

水利水电工程项目是指在一定约束 条件下, 按照一个总体设计进行施工建 设。以人、材机、时间等资源为核心的 一种全方位组织协调管理, 从而达到水 利水电项目的预定目标为目的。由于水 利水电工程往往规模大、施工单位多、 现场工地分散、施工对象复杂、管理形 式多变、施工难度大、技术复杂以及招 用大量综合素质普遍较低的民工等诸多 因素, 均会对水利水电工程建设管理带 了不同程度的影响。一旦发生事故, 不仅 会威胁国家和企业的经济发展, 还会极 大地威胁周边群众的生命和财产安全。 为此, 提高水利水电项目建设的管理水 平和效率至关重要。在水利水电工程施 工中, 管理者能行之有效的协调好各方 面的影响因素, 为水利水电工程的顺利 完成打下坚实的基础。

\section{2 水利水电工程管理的必要性}

水利水电工程是社会基础设施建设 中最常见的工程, 具有工期长、投资大、
规模大、涉及面广、投资回报长、技术 水平要求高等特点, 是一项复杂的系统 性工程。为区域供水、发电、灌溉、航 运、养殖等发挥大作用, 是促进社会稳 定、经济社会全面发展、造福人民的重 点民生工程。加强水利水电工程建设管 理意义重大, 必须加以重视。然而, 由于 现实建设中, 水利水电工程建设因涉及 面广, 参与的人员、设备、技术种类多而 杂, 加上地质地理条件的影响, 工程建设 管理较为困难, 经常会产生各种各样的 问题, 影响了水利水电工程建设的顺利 进行。预防和控制这些问题造成的不良 影响, 对水利水电工程建设及后期的维 护管理、发挥工程建设的效用十分必要。

\section{3 水利水电工程建设特点}

3. 1专业性强

从工程建设环境来看, 主要发生于 河道、湖泊等区域, 施工作业时易受到地 形、水文等多方面因素影响。对此, 施工 应遵循因地制宜原则, 立足于现场实际 情况, 为之采取专业的技术手段, 提升施 工质量。

\section{2 功能多样化}

相较于常规工程, 水利水电工程在 发挥蓄水功能的同时, 还具有挡水、灌 水、法电等多重功能, 因此对水工建筑物 提出更高要求, 必须具有优良的抗渗性、 稳定性等。各环节施工作业中, 需以行业 技术规范为指导, 做好质量管理, 从而确
保各项功能得以有效发挥。

\section{3 安全风险大}

由于水利水电工程多建设于交通不 便的山地区带, 在基坑开挖、边坡支护、 隧洞爆破等环节施工作业时存在较多危 险, 为确保安全施工作业, 就必须落实安 全第一的原则, 创建可靠的安全制度并 将其落实至实际之中, 尽可能改善现场 的管理, 营造一个良好的施工环境, 从根 本上将排除安全隐患, 以免在施工中出 现安全事故。

\section{4施工条件差}

现场施工环境较为苛刻, 易受到暴 雨、雷电、泥石流等自然因素的影响。 对此, 需从工程现场实际情况出发, 编制 完善的施工方案, 在此基础上综合考虑 现场施工状况, 为之采取灵活调整措施, 以便提升技术方案与工程实况的相适性, 为施工作业提供指导。

\section{4 水利水电工程的施工管理措} 施

4. 1 施工管理及施工质量细节把控 水利水电工程管理及施工质量控制 过程中, 应该在管理和质量控制的细节 方面加大力度, 不仅可以加强水利水电 工程建设的管理效果, 还可以提高水利 水电工程建设项目的整体施工质量。对 此我们应该不间断的加强管理人员和施 工人员的培训工作, 提升他们的专业素 养和施工技能, 让他们从思想上认识到 
水利水电工程管理对工程建设过程中的 质量控制具有极其重要的作用, 使他们 在工作时能为水利水电工程管理及施工 质量控制的制度落实提供更多支持和帮 助。还要加强对水利水电工程施工过程 的监督与管理力度, 工程中出现质量问 题及时进行解决, 严重的质量问题须责 令施工单位立即返工整改, 从工程建设 各环节保障水利水电工程建设项目的施 工质量。严格落实 “三检制”。确保施工 各个环节都符合国家或行业相关规范和 技术标准要求, 满足工程建设需要。

\section{2 规范化成本管理}

对一个水利水电工程企业而言, 其 成本管理的规范化程度决定着企业的综 合竞争能力的高低, 这需要企业在施工 期间高度重视施工费用的成本管理, 并 确保在施工过程中不浪费资金的情况下, 不仅能有效地实现建设目标, 还能提高 水利水电工程的质量水平和效率。在企 业的成本管理中, 成本控制是最重要的 组成部分之一。在规范化的成本管理基 础上, 管理者能够在施工期间做好成本 监督工作, 及时纠正经费使用偏差, 在成 本计划的范围内提高成本利用率, 提高 水利水电建设管理的效率, 实现企业经 济效益和社会效益的最大化。

\section{3技术管理}

水利水电建设存在工程规模大, 建 设周期长, 施工技术复杂, 质量要求高, 工程限制严格以及工作环境艰苦、不安 全因素相对较多等特点; 技术管理是对 水利水电工程管理中的一切技术活动进 行科学的管理和严密的组织, 使科技转 化为生产力, 从而提高经济效益。提高效 益的保障是安全, 安全的核心是管理、管 理的结果是效益。进行管理单位, 实行企 业管理, 一是内部生产经营管理粗放, 缺 乏奖励机制, 二是传统就业制度过于包 容, 致使企业人员文化程度较低、技术素
质差, 大部分职工没有受过正规培训, 缺 乏应有的技术知识。

4. 4施工安全的管理

施工安全是工程建设企业健康发展 的命脉。它能保证施工平稳的进行, 也就 是间提升施工质量。在水利水电工程的 建设中, 施工企业必须做好施工安全的 宣传工作, 给工人配置安全保护措施。与 此同时, 施工企业还应该定时对施工人 员进行安全思想教育, 让施工者提升自 己的安全意识。加强施工管理制度与工 人提高自身安全意识二者相结合, 能起 到双重作用并进一步规范施工行为, 避 免违章施工现象, 这些都能在一定程度 上避免安全事故的发生。

在职工中形成 “抓安全就是抓生产 的综合性治理”, 从而是职工做到安全生 产警钟长鸣, 平时加强职工培训, 提高整 体素质, 水利水电工程的施工中属于技 术密集型企业, 对人的素质要求高。工作 人员要身兼电气、机械和运行工作, 设备 检修时才抽调运行人员出来参加检修。 随着科学技术的发展, 不少小水电厂已 广泛应用先进的设备和技术, 现有职工 缺乏应有的知识, 在工作中感到吃力。所 以加强职工的技术培训, 提高职工的技 术水平是小水电厂发展的必由之路。

\section{5加强施工质量管理}

(1) 应加强工程的规划设计。高质量 的工程可行性调查研究报告、工程规划 设计、工程施工组织计划是项目得以顺 利进行的先行工作, 招投标时, 必须选择 最优规划设计方案, 设计科学性、可靠 性、安全性、经济性相结合的方案, 才能 初步保障施工质量。

（2）应加强材料管理。应聘请专业 的、具有一定法律知识和高度职业道德 的材料采购人员, 选择优质材料, 保障供 应商的供应能力和售后服务水平。减少 材料运输过程中的损害, 加强材料入场
检验, 提高材料的储存管理水平, 严格材 料的取用程序, 确保每一份材料都如实 的运用于水利水电工程建设中。

(3) 加强施工技术管理。良好的施工 技术是工程建设得以高效完成的基本保 障, 应选用有大型项目建设经验的施工 团队, 确保现有的技术水平能满足施工 需求。

(4) 应加强设备管理。水利水电的施 工, 经常需大型设备辅助施工, 购买也好, 租借也好, 应保障设备的整体性能, 设备 使用人员的专业水平, 定期维护管理, 保 障设备正常运行。

（5）加强人员管理, 尤其是施工技术 人员。人是项目建设的核心, 必须加强水 利水电工程施工人员的管理, 尤其是施 工技术人员, 应确保其持证上岗、有良好 的职业操守, 积极创新, 节约成本, 按照 相关施工规范和施工工序认真完成施工 任务。

（6）良好的施工现场环境是整个工 程建设的有力保障, 应为水利水电的施 工创建安全、有序的环境。

\section{5 结语}

综上所述, 本篇文章主要是分析了 当前水利水电工程管理的基本现状, 明 确了存在的相关问题, 进而在新的发展 形势下, 对怎样提升工程管理水平进行 了多层面探索, 这对于加快新形势下水 利水电工程建设具有重要意义。

\section{[参考文献]}

[1]陈元昌.现代化水利水电工程管 理现状及改进策略研究 [J]. 南方农 机,2018,49(4):169.

[2]唐亚军.水利水电工程施工管理 存在的问题与完善措施 [J]. 四川建 材,2018,44(2):223-224.

[3]陈云.水利发电工程建设与管理 的有效措施探讨 [J]. 黑龙江水利科 技,2018,46(4):140-142. 